\title{
Audience Study as Catalyst in Sustainable Nollywood Yoruba Film Industry
}

\author{
Adejoke Adetoun Ademuyiwa \\ Olabisi Onabanjo University, Nigeria \\ jokemuyiwa@hotmail.com \\ \& \\ Eunice Uwadinma-Idemudia \\ Redeemer's University, Nigeria \\ uwadinma-idemudiae@run.edu.ng
}

\begin{abstract}
Nollywood is the representation of the socio-cultural apparatus of Nigeria in the world cinema. This paper evaluates generally, film audience's perspective in Nollywood films, and in particular non-native actors in native films. Most often, stakeholders in the film industry do not access, or are flagrantly ignorant of viewer's feedback on the state of their production in all media of communication. Some determine this with the profit margins. This paper therefore evaluates the audience's perception of non-native actors in Nollywood Yoruba native films. The area of concentration is on the quality of audience reception on native films by non-native actors. Cluster sample method is the tool of research for this paper, in which questionnaire samples were distributed among film viewers in the Yoruba speaking area in Nigeria. This is done in order to determine the performance ratings of non-Yoruba native actor's skill of character interpretation in cultured films. Theoretical framework is anchored on Bandura's Social Learning theory, which concentrates on impact of artistic models on the audience's psyche. Findings reveal that audience ratings of non-native actors in Yoruba cultured films is poor, compared with their characterization in non-native setting, and this is due to wrong casting by directors who cast them against all odds in order to improve their profit margin. Findings also reveal the importance of audience study as a necessity in pre-production considerations of film shooting.
\end{abstract}




\section{Introduction}

Audience feedback discourse is an important area of art and which has not been given attention. In any dramatic expression, the audience is the main source material and the consummate structure which all other dramatic elements hang. Society remains the source of material for works of art because art reflects the society which births its art. Despite the seeming importance of the audience to both film and theatre sector, Adeleke (1995) observes that "critical work on the theatre audience is scanty" (7). In line with this thought, Ekwazi (1984), enjoins scholars to do more research on film audience to fill the vacuum for audience research in film studies. Audience research and analysis is therefore necessary in order to provide information towards the fulfilment of these elements of drama which includes theme, language, setting plot and resolution.

The audience or the viewers are the content evaluator and an important segment in element of drama. Adedokun (2001) corroborates thus, "audience research is a scientific means of evaluating the nature of audience in terms of their demographic attributes, consumer habits and other characteristics which provide useful information for planning, decision making and target marketing that are fundamental management functions" (7). Nollywood Yoruba is the socio-cultural representation of the African/Yoruba, in films of the dramatic genre. Adebanjo (2011:173) describes it as "The Nigerian Film Culture" films which depict the indigenous Yoruba society from their historical development in the pre-colonial era to the present. These films bring to fore the culture of the society through its theme of religion, history, occupation delivered in Yoruba. Some of these indigenized films include, O'tura Oríko’, a film by Yemi Amodu, Orogún Adédigba by Yewande Adekoya, Aș̣à, by Fathia Balogun, Ifá I wà, by Abdul Lateef Titilope, and Akàlàmàgbo', by Tunde Ola Yusuf. Some of the actors who fall into the non-native category include Ibrahim Chattah, Fathia Balogun, Rikado Agbor, Toyin Aimakhu to mention but a few. This group of actors are non-Yoruba actors, cast in indigenous Yoruba movies. The concern of this paper is to evaluate the audience's response to the performance of these non-native actors in Yoruba films.

Nativity is the concept of belonging to a birthplace. It is an identification of ethnicity, either by birth or origin. Romaine (2004) describes nativity as the idea of "sharing the sense of 'groupness' or 'peoplehood." (387). The socio-cultural sensibilities of a community play vital important roles in creating an identity of any individual including thought pattern which is processed by the language and culture of the immediate environment. Other concrete and non-concrete elements of nativity includes but are not limited to socio-cultural clichés; gesture; body and spoken language; dressing; hairdo; and 
occupational engagement. Non-native Yoruba actors are cross-cultured actors, whose identity is localised in different ethnic settings in Nigeria, other than Yoruba. The outcome in performance done by the actors result in most of these aforementioned actors not measuring up to the level of believability due to the socio-cultural expectations required in core Yoruba traditional films. The resultant effect is cultural disorientation on Yoruba cultural cognition among the viewers; especially those who look up to cultured films to upgrade their Yoruba ideological literacy. Most directors dance to the tune of marketers who dictate the type of cast for their plays. At the detriment of professional conduct in casting, the marketers subscribe to engage popular actors, who are well appreciated by the audience with the hope that these actors, even if they are unfit for the role, could widen their profit margin. These non-native actors in native films consequentially underplay nativity due to their failure to acculturate in between different cultures, particularly Yoruba culture. Adeleke (2009) gives a concise description in Wale Ogunyemi's production of Sango with a non-Yoruba native cast, Albert Aka-eze. "The casting and the use of bilingualism with special reference to Albert Aka-eze as Eliri, demean the quality of the production, as he is unable to render any memorable incantations. The same thing goes for Wale Adebayo, who plays the role of Sango, he fails to attract or iconize the awesomeness of Sango as Duro Ladipo did" (141). Such underplay of nativity will not escape the critical audience's judgement as a default in characterization.

\section{The Audience}

Hansen (1986) describes the audience as "a passive consumer of a fully prepared experience" (271). Most importantly the audience is an important segment in the realization of a work of art, and in most cases, the nature and responses of the audience are determinant factors in its success. Malomo (2001) also opines that audience can be fiercely loyal if they can experience fulfilment and realization in the arts experience.

\section{Audience's Influence}

From the audience's perspective, the only shortfall of film as against the stage audience is the actor/ audience interaction which is lacking, but that does not rub off the influence of film art on the audience. Avaungwa et al (2012) also observe that, "as the advent of home videos affects and influences life patterns, viewers acceptance of the film video also creates room for assimilation of practices that are useful for community development, thus, creating a symbiotic relationship between the creator and the consumer of artistic product" (45). 
Presently in Nigeria, most home video films are shown in the theatre or cinema halls using the $35 \mathrm{~mm}$ projector. The film audience in cinema still reacts positively or negatively on the actor's performance, the difference is that actors cannot be influenced by the audience's reaction unlike the live performance. Hansen (1986) explains further that "time and distance has intervened. The film may be an excellent work of art, but the audience is forced to deal with it in much the same way that one experiences a painting" (17).

The audience's influence cannot be overemphasized. Hansen (1986) is of the opinion that,

Not all influences are direct and immediate. There can be no doubt that the audience has been indirectly involved from the very beginning. When the playwright's first idea began to take shape, it was with an audience in mind; he or she had something to communicate and, without question, it was to an audience. The director developed a concept for an audience. The designers, the actors, the technicians, the publicist, all went about their work with at least some dim idea of - an audience. In every person's imagination there were, from the very outset, always, the question was- how will this read to an audience (263).

It is important to know that the Yoruba Nollywood film audience is an important segment in the realization of a movie. From personal observation, the nature of the audience is a determinant factor for its success at the box office. The target audience is the first idea which prompts the writer to write the play. Such target audience includes the youth, underage, and adults whose behavioural patterns form the theme of the drama. That is why most films carry out the inscription "For Parental Guidance only" or "this film is not suitable for persons under the age of sixteen." There are variations in audience types. Vincent, (1981) identifies four types of audience: the semi illiterate, educated, illiterate, and the campus audience. Adeleke (2009) identifies three types, which he describes as "a lay audience, an average audience, and a super audience" (17). For the purpose of clarification, both Adeleke's and Vincent's audience typology can be reclassified thus: campus, educated, and super audience may be categorised as the 'critical (elitist) audience' who have been exposed to Western education while the lay audience, illiterate, and semi illiterate may be classified as the 'uncritical (non-elitist) audience.'

\section{The Uncritical audience}

This category of audience can be averagely elitist, semi illiterate or non-elitist, who derive pleasure in the choices of actors, regardless of the form and 
content of the drama. Adeleke (2009) reiterates further that the set of a lay audience which is uncritical have little or sparse linguistic knowledge of the communication medium (75), what this means is that in so far as the actors can communicate, conversationally, they are less concerned about the skill or default in language because their exposure to the intricacies of language is limited. Karen Barber (1987) identifies only one audience for Yoruba drama as "the radical conservative audience" (15). She describes them as less educated, less paid, from the lower layer of the society (15). They are the popular or general audience. Vincent (1981) observes that the popular play tends to unite the stage and players and, besides, the popular play utilizes Nigerian language, especially Yoruba. This group of audience care less about the technical or creative details needed for a film or play to be successful, as they simply want entertainment. Their excitement is limitless as soon as they cite their favourite actors on the screen, they become expectant, since they learn a few antics from the actors (Olatunji and Ogundeji 1990). This category is not limited to the popular literate or illiterate audience. Research on this study shows that, most times, their choices of actors include the comic actors even in serious interpretation of roles. Such actors include comedians like Baba Suwe, Golugo, Latin, Sanyeri, or the Babalawo type cast of Lalude and Alebiosu, actors who are capable in performance to relieve audience's day-to-day tension and occupational fatigue.

The uncritical audience is common among Nigerians in the diaspora. Some Nigerians living abroad are prone to buying films which include the aforementioned actors, who will inject variety in their everyday rote and who will bring contrast to the rigid mental atmosphere of orderliness as seen in non-African setting, in order to maintain emotional balance. The typical African setting is community- and family-bound society with limitless instructiveness that is not available in the western world. The aim of this type of audience is to release tension by watching films. They are easily attracted to themes of supernaturalism, which remind them of home culture and religion, domestic fight and violence, comedies: the stupid gateman or house maid, typical of characters in Commedia de Larte of the classical and medieval period in Europe. The aggression of Sola Sobowale in domestic themes, the rascality of Odunlade Adekola, the half literate Jennifa by Funke Akindele, the stupidity of Golugo, the abusive words of Lanko, Eleso and Ijebu. Most of these stereotypes are cast in both cultured and modern-day movies as servants, gatemen, half-literate characters and greedy family heads.

\section{The Critical Audience}

This type of audience is the elitist educated type, who views films from the eye of the critic, paying attention to all elements of drama on the screen in 
terms of the form and content and, also, keen on assessing the skill of character interpretation. Vincent (1981) describes the elitist audience such:

The educated audience in its own case belongs to the middle class of the society. This group of audience has had exposure to drama at school either through literature or participation in performing troupes. It takes an interest itinerary drama, which requires serious intellect on the part of the audience and knowledge of theatre to decipher the meaning of plays (81)

Ohenhen (2015: 236) observes that "the audience or customers of the $21^{\text {st }}$ century are highly selective and hard to please, with a flurry of competitive entertainment and recreation option, more so as they are bombarded with a flurry of competitive entertainment and recreation options" (236). Drama audience can be equally divided into two: the film audience and the theatre audience, depending on choice, and in most cases, others appreciate both.

\section{Role of the film Audience}

Winsatt and Beardsly (1973), Euba, (1981), Malomo, (1985) agree that performance is done solely for the audience. Olusola, (1981) reiterates further that audience reaction to television programmes is the main concern of producers and television station. Adeleke (1995) is of the opinion that they are the pillars, life and strength including the market which is the ultimate value in film appreciation.

The audience define film art as a social means of expression. Adeleke (2003) is of the opinion that the film audience upgrades the commercial value of movie at the cinema, or through film disc purchase, and, profit is also diverted towards research for another film production. According to Adeleke (2003), "the film audience are active representative of the society", (2). The audience dictate the social trend through appreciation and emulation of their role model, which is the actors; hence producers go a long way to satisfy them through film content. They celebrate the actors; hence actors become celebrities through audience appreciation. Adeleke (3) opines that influential and rich members of the audience serve as patrons, giving financial aid to film makers in the pursuit of their art (Adeleke 2002:3). He cites the example of Rasheed Ladoja, former governor of Oyo state, who gave financial backing to Tunde Kelani, the director of Main Frame Productions, as a result of audience/film relationship. It is important to know that, through the audience patronage at the cinema, they create jobs for actors, Adeleke (2003) posits that "a number of people who would have been unemployed in the labour market who now take to acting in order to provide for their livelihood from the gate fees paid by the theatre goers" (5). They can influence writers to produce, 
and in most cases, they serve as the source material most times, they provide the locations for directors to shoot their film. The audience emulate fashion, hairstyle, and clichés as social trend from the actor. The audience dictates the content in all elements of the drama such as theme, setting, characterization and the period. The audience is the main contributor or stakeholder in arts economy.

\section{Factors Militating against a Positive Response and Arts Appreciation}

Apart from the dearth of materials on audience study, which prevents the stakeholders of film production to conduct survey analysis before the next production is embarked upon, Onabajo (2009) observes that, the main conflict in audience's positive response to video film appreciation stems from poor production quality. He notices that most producers do not make adequate plan for quality films. Most marketers, video club retailers and the viewing audience, especially the uncritical audience are not better, they have limited sense of value for quality, but for quantity so far it meets their selfish ends. Because of this, a good percentage of the critical audience are no longer satisfied with most films. Another reason for the dissatisfaction is the number of films released in one week. Agoi (2001) gives a specific number of films released in a year as ranging from 250 to 650 per year. In a rush to make movies, many unprofessional directors and producers strive to make their own impact in the industry, regardless of any precautionary or standardized measures towards excellence, the result is a saturated market of films. The poor quality ranges from too much lighting or poor lighting, distractive background noise, uncoordinated flashbacks, poor continuity, poor dialogue, lack of suspense, distorted historical fact, lack of research, poor acting, and crude delivery. Obilade (1987) opines on inherent ambiguity in language through cultural constraints in communication. These problems may not be visible in parts but as a whole, in the general overview of the production.

Most non-Yoruba native actors are cast in Yoruba indigenous movie simply because they had been widely appreciated in modern Yoruba movies with themes ranging from violence, horror, domestic abuse, betrayal and all sorts, and this set of actors, who are multilingual have in one way or the other dictated the trend of fashion, patterns of living, through characterization and their linguistic medium, which is the modernized Yoruba dialect. The sociolinguistic interference of mother tongue, which is not Yoruba, makes their interpretation defective, causing serious disorientation for the consumers of cultured movie product. Hence the audience with a preference or deep 
appreciation for language and culture as projected in these movies easily lose interest in the credibility and interpretative skill of these so called "celebrities"

\section{Research Methods}

This study employed survey design which has to do with the observation of respondents without manipulation of variables. This involved collection of data from the respondents through quantitative method (questionnaire) and analysis of data from the research questions. The study made use of primary source of data, which is, observing the respondents directly through questionnaire. The population of the study consisted of audience from south-western Nigeria. Five hundred and sixteen (516) respondents formed the sample of the study through cluster sampling technique. The questionnaire, tagged "audience study" was developed by the researchers and validated through Cronbach's Alpha method. The reliability of the questionnaire was 0.89 .

\section{Results}

This study presents responses analysis from the main instruments used for data gathering as collated from the clustered sample of respondents. The analysis from the questionnaire reflects the performance ratings of non-Yoruba native actors' skill of character interpretation in Yoruba cultured films as assessed by the cross section of samples using the validated instruments. This essay presents results and analysis of findings in accordance with the research questions under the following sub headings:

Research Question One: What is the level of preference of the respondents' audience for Yoruba films?

\begin{tabular}{|l|l|l|}
\hline Types of Yoruba Films & Yes & Percentage (\%) \\
\hline Modern Yoruba Films & 326 & 63.2 \\
\hline Culture Yoruba Films & 190 & 36.8 \\
\hline Total $^{*}$ & 511 & 99.0 \\
\hline
\end{tabular}

Table 1: Preference of the Respondents' Audience for Yoruba Film Types $(\mathrm{N}=516)^{1}$

Table 1 reveals that majority 326 (63.2\%) of the respondents prefer modern Yoruba movies than the cultured movies. It implies that Yoruba modern movies have wider patronages and preference than cultured movies in Southwestern Nigeria.

Research Question Two: What is the view of respondents' audience on cultured films? 
Audience Study as Catalyst in Sustainable Nollywood Yoruba Film Industry 299

\begin{tabular}{|l|l|l|}
\hline Views on Yoruba Films & Yes & Percentage (\%) \\
\hline Very good & 204 & 39.5 \\
\hline Good & 243 & 47.1 \\
\hline Bad & 46 & 8.9 \\
\hline very bad & 23 & 4.5 \\
\hline Total $^{\star}$ & 515 & 99.8 \\
\hline
\end{tabular}

Table 2: Views of Respondents' Audience on Cultured Films $(\mathrm{N}=516)^{2}$

Table 2 shows that a slight majority of 243 (47.1\%) viewed Yoruba cultured film as good and 204 (39.5\%) viewed Yoruba cultured films as very good. Finding implies that larger audience have positive views about Yoruba cultured films in Southwestern Nigeria.

Research Question Three: What is the perception of the respondents' audience about Non-Yoruba actors in cultured films?

\begin{tabular}{|l|l|l|}
\hline Ratings of Polyglot Actors & Frequency & Percentage (\%) \\
\hline Good & - & - \\
\hline Poor & 421 & 81.9 \\
\hline Indifferent & 93 & 18.1 \\
\hline Total $^{*}$ & 514 & 100.0 \\
\hline
\end{tabular}

Table 3: Respondents' Audience Perception about Cultured Films and Featured Non-Yoruba Film Actors? $(\mathrm{N}=516)^{3}$

Table 3 shows that $81.9 \%$ of the respondents observed that non-Yoruba actors in cultural films are poor in linguistic interpretations and native cultural nuances, while $18.1 \%$ of respondents were indifferent in their assessment. Non-native actors studied, were deficient in standard Yoruba competence and linguistic interpretation of roles in native movies. In summary, respondents' perception about cultured films that featured Non-Yoruba film actors could be described as poor.

Research Question Four: What is the perception of the respondents' audience on the quality of Yoruba films, language formats, and cultural portrayal?

\begin{tabular}{|l|l|l|}
\hline $\begin{array}{l}\text { Views on Yoruba Films Language and Cultural } \\
\text { Portrayal }\end{array}$ & Yes & Percentage (\%) \\
\hline Very good & 225 & 43.6 \\
\hline Good & 240 & 46.5 \\
\hline Bad & 32 & 6.2 \\
\hline
\end{tabular}




\begin{tabular}{|l|l|l|}
\hline very bad & 19 & 3.7 \\
\hline Total $^{*}$ & 509 & 98.6 \\
\hline
\end{tabular}

Table 4: Respondents' Perception of the quality of Yoruba films, language formats, and cultural portrayal $(\mathrm{N}=516)^{4}$

Table 4 shows that majority 465 (90.1\%) of the respondents have positive perception of the quality of Yoruba films, language formats, and cultural portrayal. In summary, the result revealed that targeted audience have very good and positive perception about Yoruba films.

Research Question Five: What is the perception of the respondents about non-Yoruba actors' exclusion in cultured films?

\begin{tabular}{|l|l|l|}
\hline $\begin{array}{l}\text { Exclusion of polyglot actors in } \\
\text { Yoruba cultured films }\end{array}$ & Percentage (\%) \\
\hline Yes & 421 & 81.9 \\
\hline No & 93 & 18.1 \\
\hline Total $^{*}$ & 514 & 99.2 \\
\hline
\end{tabular}

Table 5. Respondents' perception of polyglot exclusion in Yoruba cultured films $(\mathrm{N}=516)^{5}$

Table 5 shows that majority 421 (81.9\%) opined that non-native actors should be excluded in native films. In summary, findings from this study revealed that targeted audience in Southwestern Nigeria want non-native actors to be excluded in Yoruba cultured films.

\section{Summary of Findings from the Respondents' Audience}

Majority responses indicated that Yoruba movies in contemporary setting have wider patronages and preference than movies with cultural themes in Southwestern Nigeria. A small percentage especially in the elite or campus audience category prefers films in the contemporary setting. The findings include that a larger percentage of the targeted audience have positive views about Yoruba cultured films in Southwestern Nigeria. Again, respondent's perception about native films that featured non-Yoruba native actors could be described as poor. Lastly, findings from this study revealed that targeted audience in Southwestern Nigeria rated non-Yoruba actors featured in Yoruba indigenous film as poor.

\section{Discussion of Findings}

Distribution of questionnaire for this research cuts across various communities in Yorubaland, academic and non-academic. The age range is between 
16-36. From the 1,000 copies of questionnaire distributed, only 516 responded, while 486 returned the questionnaire unanswered. The findings also reveal that the age range between $16-25$ is active viewers.

The modern contemporary audience prefer movies of modern setting to the cultured ones, but also agree that the few cultured movies they watch are good. On the good ones, findings also reveal that their ratings of non-Yoruba actors' performance in Yoruba indigenous movies are only poor, not very good; and in fact, while more respondents observe the non-native inability to acculturate and do not wish they participate in such movies, a low average agree that their nativity does not affect their performance especially in terms of the expression of language. Hence for the low average respondents, they wish to see the non-native actors again. Generally, the findings agree that the aesthetic and the artistic quality of non-Yoruba actors in cultured movies is an evidence of underplay of nativity. These findings also reveal the necessity for serious research work on audience perception especially on similar productions of native movies. The findings also reveal that the audience can be critical to the point of outright condemnation of the film, since the medium of communication is deficient, the concern of producers as stakeholders is to be professional in all segments of production especially in the choice of cast by choosing the right cast for the Yoruba indigenous movies.

\section{Conclusion}

From the data analysis, this essay concludes that movie audience in the Southwestern part of Nigeria cuts across age and gender in their reception and appreciation of movies in the traditional setting. Majority of non-Yoruba actors in Nollywood Yoruba cultured movies are not versatile enough to be engaged in Yoruba native movies. The function of such movies includes the preservation of culture and historical facts, which is a reflection of their nativity and which is germane to the developmental structure of the immediate environment. There is a relationship in the social context between the audience and the stakeholders of the industry, hence, they have moral responsibility to always create and maintain standardized movie for their audience, since the audience are the customers, and the customers are always right. In order to sustain the customer service and relationship for the benefits of all stakeholders, the questionnaire in Appendix A is designed to sample audience opinion to enhance the service provider and consumer values.

This paper suggests that stakeholders in the Nigerian Nollywood/film industry should as a matter of necessity conduct interviews regularly with the audience to gather responses that can assist them in the decision process film making. Actors too should be educated in formal and informal training in order to sustain the interest of the audience who are the major consumers of 
their act. The actors' guild should organize seminars for updates on acceptable best practices for production, pre-production, and post production information, to meet with the demands of their target audience.

\section{References}

Adebanjo, N. "Cultural Studies: Theories." In Concepts and Practice. Ahmed Yerima and Olu Obafemi (eds.). Lagos: Centre for Black African Arts and civilization, 2011, pp. 173-185.

Adedokun, A. Arts Administration in Nigeria, Lagos: Centre for Black African Arts

and Civilisation. 2001.

Adeleke, Duro. "Audience Reception of Yoruba Films" Unpublished Ph.D. dissertation, University of Ibadan, Nigeria. 1995.

Adeleke, Duro. "Aye Ati Ipa Onworan Ninu Tiata Ati Fiimu" Langbasa: Jona Ise Akada ni ede Yoruba. Vol. 10: (2003):1-10.

Adeleke, Durotoye. "Reconfiguration of Sango on the Screen" In Sango in Africa and The African Diaspora. John Tishken, Toyin Falola and Akintunde Akinyemi (eds). Bloomington and Indianapolis: Indiana University Press, 2009, 135-156.

Agoi. Olatunde. "Nigerian Rapid fire Video Booms". The Punch. 2001. June $29 \mathrm{pp} 23$.

Avaungwa, Gbilekaa. "Influencing Target Audience for TfD and Nollywood Practice in Selected Media Services." Nigerian Theatre Journal. A journal of The Nigerian Theatre Artist. Vol 12, No 1. (2015):45-54.

Barber, Karin. "Radical Conservatism in Yoruba Popular Plays." In Drama and Theatre in Africa. Eckhard Breitinger (ed.). Bayreuth: Bayreuth African Studies Series, 1987, pp. 5-20.

Euba. Akin. "The Nigerian Theatre and the Playwright." Drama and Theatre in Nigeria: A Critical Source Book. Yemi Ogunbiyi (ed.). Lagos, Nigerian Magazine Special publication, 1981, pp. 381-398

Ekwazi, H. O. "Film in Nigeria: The Context of Production" Unpublished Ph.D. dissertation, University of Ibadan, Nigeria. 1984.

Hansen, Brian. Theatre: The Dynamics of the Arts. Prentice Hall: Englewood Cliffs. $2^{\text {nd }}$ Edition, 1986.

Malomo, Jide. "Theatre and Audience Research." Arts Administration in Contemporary Nigeria. (ed.) Remi, Adedokun. Lagos: CBAAC, 2001, pp 89-112. Obilade, Tony. "Meaning and The Communication Arts." Topical Issues in Communication Arts. (ed.) Unoh, S.O. Uyo: Modern Business Press Ltd. 1987, pp.58-70. 
Ohehen, Stanley. "Entrepreneurship and the Economic Relevance of Africa's Creative Arts and Culture Industry in the $21^{\text {st }}$ Century Global Economy" Ibadan Journal of Theatre Arts, 9\&10, (2015): 225-246.

Olatunji O., P.A. Ogundeji. "Ipa ti Ere Ori Itage ko Lawujo." Aayan awon Omoran lori Imo Ijinle Yoruba. O. Olatunji (ed.). Ibadan: J.F Odunjo Memorial Lectures Organising Committee. 1990, pp. 57-87.

Olusola. S. "The Advent of Television Drama in Nigeria". Drama and Theatre in Nigeria, Yemi Ogunbiyi (ed.). Lagos, Nigerian Magazine Special publication, 1981, pp. 370-380.

Onabajo, Ritchard. "Emergence, Growth and Challenges of Films and Home Videos in Nigeria." Maryland, USA. African Renaissance Books Inc. 2009, pp. 9-25.

Romaine, Suzan. "The Bilingual and the Multilingual Community." In The Handbook of Bilingualism. Tej K. Bhartia and Williams C, Ritchie (eds.). Cambridge: Harvard University Press: 2004, pp. 387-401.

Vincent, Theo. "Theatre and Audience in Nigeria." Black Orpheous, Vol .4:1, 1981. 80-84. 


\section{APPENDIX A}

\section{Questionnaire on Audience Study}

SECTION A

Instruction: Please read carefully and fill in the correct information to the space below

Name of Respondent:--------------------

Age :

State of origin:

Gender: Male ( ) Female ( )

SECTION B

Please read each items carefully and tick appropriately the column that best suits your opinion.

1. What type of Yoruba movie do you like? Modern ( ) Cultured ( )

2. Your view about Yoruba cultured film? Very good ( ) Good ( ) Bad ( ) Very Bad ( )

3. Can you rate the quality of the movies? $40 \%$ ( ) $50 \%$ ( ) $60 \%$ ( ) $70 \%$ ( ) $80 \%$ ( ) $90 \%$ ( )

4. How is language culture portrayed? Very good ( ) Good ( ) Bad ( ) Very Bad ( )

5. How many cultured movies do you watch in a month 10 ( ) 20 ( ) More ( ) None ( )

6. How do you rate non-Yoruba actors in an indigenous movie? Very good ( ) Good ( ) Bad ( ) Very Bad ( )

7. Does their nativity affect their character? Yes ( ) No ( )

8. Who are your favourite non-Yoruba actors in Yoruba cultured movies? (please specify) 